\title{
Effect of Erythrocyte Destruction on Carbon Monoxide Production in Man*
}

\author{
R. F. Coburn, $\dagger$ W. J. Williams, + and R. E. Forster \\ (From the Department of Physiology, Graduate School of Medicine, and the Department of \\ Medicine, School of Medicine, University of Pennsylvania, Philadelphia, Pa.)
}

Recent studies performed in our laboratory (1) have confirmed the finding of Sjöstrand $(2,3)$ that carbon monoxide is produced in normal man. In 10 normal subjects the average rate of production of carbon monoxide was found to be 0.42 ( $\mathrm{SE}$ of mean \pm 0.02$) \mathrm{ml}$ per hour. The present study is an attempt to clarify the processes that result in the production of this gas in the body.

A number of studies have been performed that suggest that $\mathrm{CO}$ may be an in vivo catabolic byproduct of hemoglobin. Sjöstrand and associates have demonstrated that the blood carboxyhemoglobin concentration [ $\mathrm{COHb}$ ] becomes elevated in man after intramuscular or intravenous injection of blood or hemoglobin (3) and intravenous injection of damaged erythrocytes or nicotinic acid (4). Sjöstrand (3) and later Engstedt (5) and Oski and Altman (6) noted that the blood [COHb] level is elevated in patients with hemolysis. Chemical studies by Sjöstrand $(7,8)$ and Ludwig, Blakemore, and Drabkin (9) have demonstrated that treatment of hemoglobin $(7,8)$ and pyridine hemochromogen (9) with hydrogen peroxide and ascorbic acid results in $\mathrm{CO}$ formation. In the latter study the bridge and adjacent carbon atoms of heme were labeled with $\mathrm{C}^{14}$, and the $\mathrm{CO}$ formed was found to be radioactive, indicating that $\mathrm{CO}$ probably arose from a methene bridge carbon atom.

* Submitted for publication November 18, 1963 ; accepted January 30, 1964.

Presented in part at the 47th annual meeting of the Federation of American Societies for Experimental Biology, Atlantic City, N. J., April 1962. Supported in part by a grant from the Life Insurance Medical Research Fund.

$\dagger$ Postdoctoral research fellow of the National Institutes of Health.

$\ddagger$ Recipient of U. S. Public Health Service research career program award HE-K3 2629 from the National Heart Institute.
There remains, however, some uncertainty concerning the relationship of hemoglobin catabolism to endogenous carbon monoxide production in vivo. The elevated venous blood [ $\mathrm{COHb}$ ] found in the above in vivo studies may not be a result of an increased rate of endogenous $\mathrm{CO}$ production, since this variable is also markedly influenced by the concentration of $\mathrm{CO}$ in inspired air, the affinity of hemoglobin for $\mathrm{CO}$, and the rate of excretion of $\mathrm{CO}$ from the body. Doubt has arisen concerning whether the chemical studies of Sjöstrand and Ludwig and associates are applicable to in vivo hemoglobin catabolism, especially since recent studies of Petryka, Nicholson, and Gray (10) have shown that coupled oxidation of heme is a different reaction than occurs physiologically during heme catabolism in that the porphyrin ring is apparently randomly opened at any of the four methene bridge carbon atoms rather than at the alpha position as occurs in vivo (11). Because of these uncertainties, our method for estimating in vivo $\mathrm{CO}$ production quantitatively was applied to this problem. This paper contains data on measurements of the rate of endogenous carbon monoxide production following the intravenous injection of damaged erythrocytes in man.

\section{Methods}

Endogenous CO production was measured by the "rebreathing method" described in greater detail elsewhere (1). The principle of this method is that $\mathrm{CO}$ excretion from the body, which occurs via the lungs, is inhibited by having the subject rebreathe in a closed system. Endogenous $\mathrm{CO}$ production is then calculated from the rate of increase in venous blood [COHb] during rebreathing and the effective blood volume, both of which are measured in every study. With this technique the production of $\mathrm{CO}$ per hour, calculated from two blood samples, drawn at the beginning and end of the period, could be estimated in each hour with an error of less than $\pm 0.2 \mathrm{ml}$. Greater precision was ob- 
tained during experiments in which the rate of $\mathrm{CO}$ production was measured by drawing and analyzing multiple blood samples. Here the error in measurement of the rate of $\mathrm{CO}$ production was less than $\pm 0.1 \mathrm{ml}$ per hour.

The hemoglobin concentrations of the blood samples were measured as cyanmethemoglobin in a spectrophotometer (12). Plasma hemoglobin concentration was measured by the method of McCall (13). Base-line values by this method in our laboratory are 5 to $10 \mathrm{mg}$ per 100 ml. Serum bilirubin was measured by the method of Malloy and Evelyn (14).

Human erythrocytes were "damaged" in the manner described by Jacob and Jandl (15). Fresh venous blood was drawn into a sterile bottle containing acid-citratedextrose (ACD) anticoagulant. The erythrocytes were collected by centrifugation and then were washed three times with cold physiological saline, and the final hematocrit was adjusted to $50 \%$. The erythrocyte suspension was mixed with an equal volume of a solution of $32 \mathrm{mM}$ $N$-ethylmaleimide (NEM) in $0.15 \mathrm{M} \mathrm{NaCl}$ giving 64 $\mu$ moles of NEM per $\mathrm{ml}$ of erythrocytes, and incubated at $37^{\circ} \mathrm{C}$ for 1 hour. After incubation the erythrocytes were again collected by centrifugation, washed once with $0.15 \mathrm{M} \mathrm{NaCl}$, resuspended, and then reinjected intravenously into the donor. In two experiments the cells treated with NEM were labeled with radiochromate (16). Venous blood samples were taken periodically after reinjection of these cells, and the erythrocyte $\mathrm{Cr}^{51}$ activity was estimated in a well scintillation counter.

After preparation of the "damaged" erythrocytes, the subject initiated breathing in the closed circuit. The $\mathrm{O}_{2}$ tension in the system was maintained at approximately $150 \mathrm{~mm} \mathrm{Hg}$ by a demand valve, and $\mathrm{CO}_{2}$ was absorbed. Fifteen minutes after the start of rebreathing a venous catheter was inserted into an antecubital vein, and the first blood sample was drawn anaerobically with a heparinized syringe. A small amount of mercury was added to the sample to facilitate complete mixing. Subsequent blood samples were taken hourly throughout the experiment and analyzed for [COHb], plasma bilirubin, plasma hemoglobin, and, in some experiments, erythrocyte radiochromate content.

Five experiments were performed with the subjects described in Table I. Four of the subjects were young male students who had normal peripheral blood hemoglobin concentrations, differential, leukocyte counts, and reticulocyte counts. The fifth subject was a 46-year-old female who was hospitalized with a pyridoxine responsive anemia. All of the subjects were either nonsmokers or abstained from smoking for 24 hours before the experiment. The "damaged" erythrocytes were labeled with radiochromate in the experiments on $\mathrm{CB}$ (Table I) and $\mathrm{BH}$, a 54-year-old white male hospitalized with an uncomplicated duodenal ulcer, on whom the $\mathrm{CO}$ measurements were not performed.

In three of the experiments ( $\mathrm{RE}, \mathrm{TP}$, and $\mathrm{PK}$ ) the control rate of $\mathrm{CO}$ production was measured for 3 hours immediately preceding the reinjection of the "damaged" erythrocytes. In two experiments (BD and $\mathrm{CB}$ ) the treated cells were injected at the start of the experiment. In all experiments, hourly $\mathrm{CO}$ production was measured for a total of 6 to 7 hours.

Because of the possibility that small amounts of unreacted NEM were injected with the erythrocytes, animal experiments were performed in which NEM in amounts equivalent to those used in the human experiments was injected intravenously into dogs, weighing 13 to $17 \mathrm{~kg}$, anesthetized with pentobarbital. $\mathrm{CO}$ production rates were determined before and after giving the drug.

\section{Results}

After intravenous injection of the "damaged" erythrocytes $\mathrm{CO}$ was produced in greater amounts in all five of the experiments as compared to the control $\mathrm{CO}$ production (Table $\mathrm{I}$ ). The changes in blood $[\mathrm{COHb}]$ and the corresponding hourly $\mathrm{CO}$ production from two of the five experiments are presented in Figures 1 and 2. The rate of increase in $[\mathrm{COHb}]$ in the 2 to 4 hours following injection of the treated cells was significantly greater in every experiment, being as much as $0.25 \%$ per hour, whereas the control rate averaged $0.05 \%$ per hour. The control rate $\mathrm{CO}$ production in the first three experiments ( $\mathrm{RE}, \mathrm{TP}$, and $\mathrm{PK}$ ) was $0.28,0.43$, and $0.46 \mathrm{ml}$ per hour. It was necessary to use assumed values for the control $\mathrm{CO}$ production in the experiments on $\mathrm{BD}$ and $\mathrm{CB}$, as will be discussed later. "Extra" $\mathrm{CO}$ was

TABLE I

Comparison of the amount of injected hemoglobin in the "damaged" erythrocytes and the "extra" CO produced

\begin{tabular}{|c|c|c|c|c|c|c|c|c|c|c|}
\hline \multirow[t]{2}{*}{ Subject } & \multirow{2}{*}{$\frac{\text { Age }}{y r s}$} & \multirow[t]{2}{*}{ Sex } & \multirow{2}{*}{$\frac{\text { Height }}{\text { inches }}$} & \multirow{2}{*}{$\frac{\text { Weight }}{l b s}$} & \multirow{2}{*}{$\frac{\begin{array}{c}\text { Control } \\
\text { CO } \\
\text { production }\end{array}}{m l / h r}$} & \multicolumn{2}{|c|}{$\begin{array}{c}\text { Hemoglobin } \\
\text { injected }\end{array}$} & \multicolumn{2}{|c|}{ "Extra" CO } & \multirow{2}{*}{ 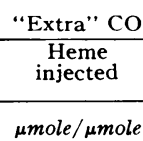 } \\
\hline & & & & & & $g$ & umoles heme & $m l$ & umoles & \\
\hline RE & 22 & $\mathbf{M}$ & 66 & 142 & 0.28 & 3.04 & 179.0 & 3.45 & 154 & 0.86 \\
\hline $\mathrm{TP}$ & 29 & $\mathrm{M}$ & 69 & 170 & 0.43 & 2.92 & 172.0 & 3.48 & 155 & 0.90 \\
\hline PK & 23 & $\mathbf{M}$ & 67 & 132 & 0.46 & 5.28 & 312.0 & 6.10 & 272 & 0.87 \\
\hline $\mathrm{BD}$ & 22 & $\mathbf{M}$ & 68 & 170 & & 3.37 & 198.5 & 5.90 & 263 & 1.32 \\
\hline $\mathrm{CB}$ & 46 & $\mathrm{~F}$ & 63 & 135 & & 1.54 & 91.0 & 1.89 & 83.5 & 0.92 \\
\hline
\end{tabular}



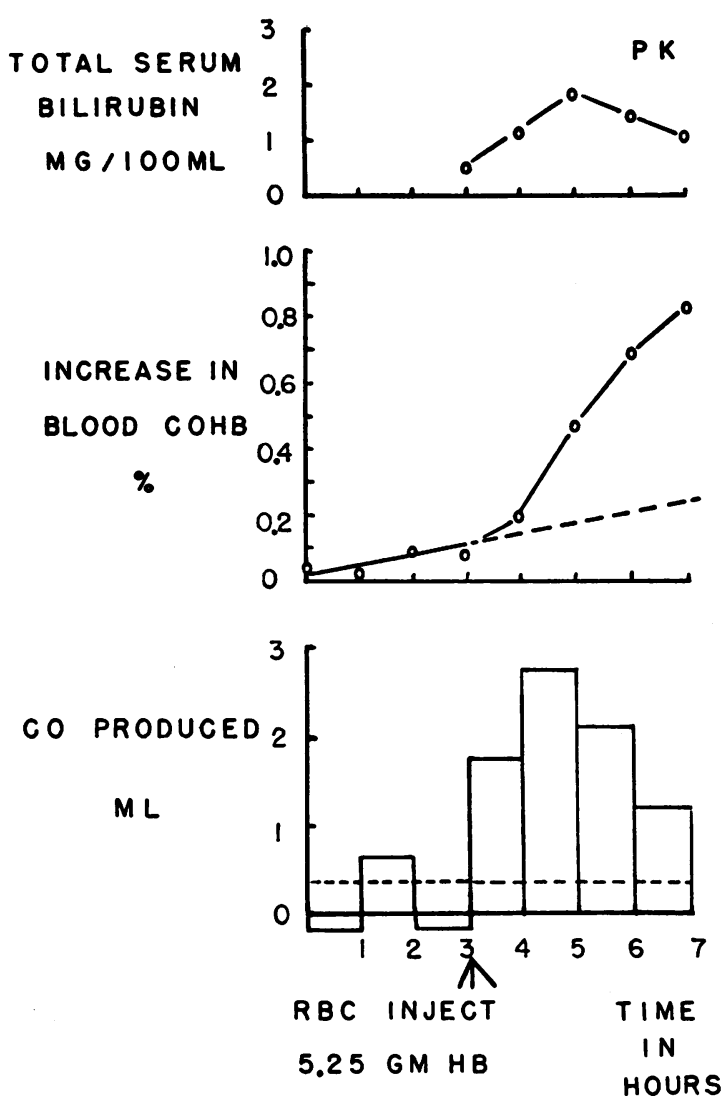

Fig. 1. EFFeCt OF ERYTHROCYTE AND HEMOGLOBIN DESTRUCTION ON SERUM BILIRUBIN, RATE OF INCREASE IN BLOOD CARBOXYHEMOGLOBIN, AND HOURLY CARBON MONOXIDE PRODUCTION. The base-line carbon monoxide production was measured during the first 3 hours of the experiment followed by intravenous injection of erythrocytes prepared by incubation with $64 \mu$ moles $N$-ethylmaleimide per $\mathrm{ml}$ erythrocytes for 1 hour at $37^{\circ} \mathrm{C}$. The dashed line in the middle and bottom graph represents the average control rate of $\mathrm{CO}$ production.

calculated by subtracting the control from the total $C O$ production, as will be discussed later. These values are listed in Table I. Up to $6.30 \mathrm{ml}$ more CO was formed in the 2 to 4 hours following injection of the cells than would have been formed in an equivalent time at the control rate.

The injected erythrocytes were rapidly removed from the vascular compartment, as expected from the work of Jacob and Jandl (15). In the two experiments employing erythrocytes labeled with $\mathrm{Cr}^{51}$, one-half of the radioactivity disappeared from the blood in seven (CB) and eleven ( $\mathrm{BH}$ ) minutes, and an average of less than $3 \%$ of the injected cells remained in the blood 1 hour after injection. The labeled cells did not return to the vascular compartment after they had been trapped at the site of sequestration.

Serum bilirubin levels increased significantly after injection of the erythrocytes (Figures 1 and $2)$. The increase in serum bilirubin levels appeared to parallel CO production.

The plasma hemoglobin increased slightly in three experiments where it was measured. Values up to $5 \mathrm{mg}$ per $100 \mathrm{ml}$ above the control levels were found in the first hour following injection of the cells, and these fell to control levels by the end of the third hour after injection. The quantity of hemoglobin appearing in the plasma was only a small fraction of the total hemoglobin administered in the cells and was not considered significant. Further, we have recently found that elevated serum bilirubin concentrations cause
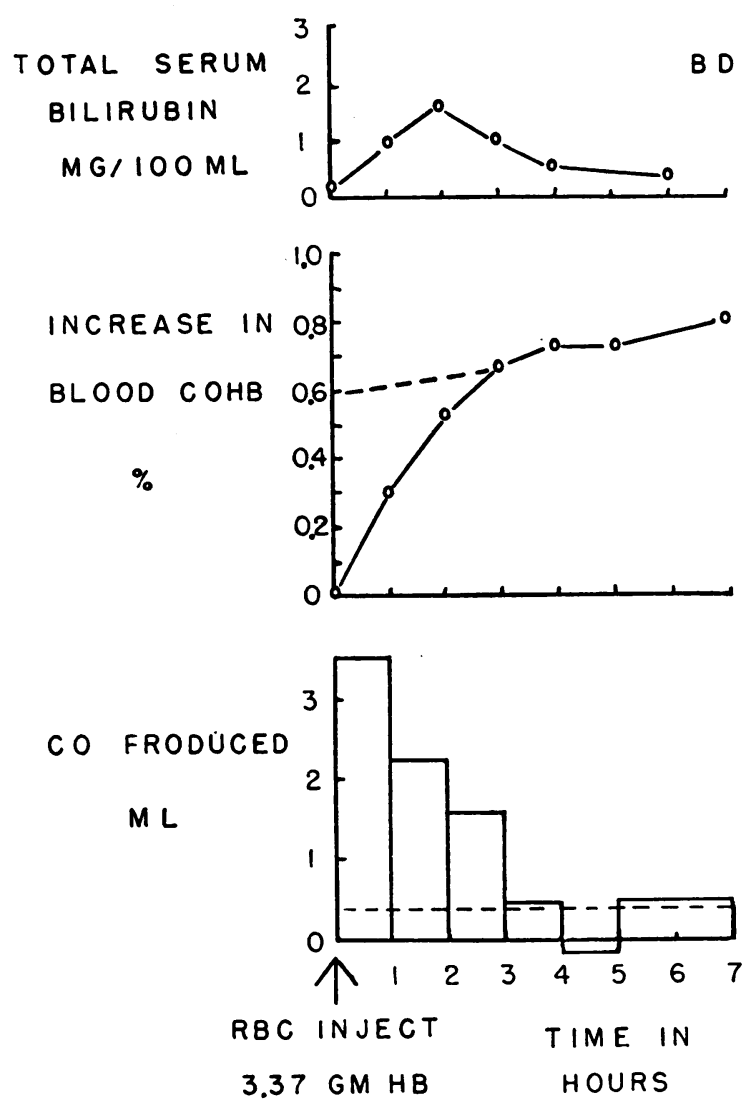

Fig. 2. EFFECT OF ERYTHROCYTE AND HEMOGLOBIN DESTRUCTION ON SERUM BILIRUBIN, RATE OF INCREASE IN BLOOD CARBOXYHEMOGLOBIN, AND HOURLY CARBON MONOXIDE PRODUCTION. The treated cells were injected at the beginning of the experiment. 
falsely high values for plasma hemoglobin by the method used, and the real increase in plasma hemoglobin was probably even less than that recorded here.

Control studies were performed on two dogs in which the rate of $\mathrm{CO}$ production was measured before and after the intravenous injection of $\mathrm{NEM}$ in saline, in quantities comparable to those used in the human studies. The base-line $\mathrm{CO}$ production rate in these dogs was one-half to one-third that of the normal human, and was not changed by administration of NEM.

\section{Discussion}

The studies reported here demonstrate that $\mathrm{CO}$ is produced in large quantities after injection of erythrocytes treated so as to lead to their rapid removal from the circulation. The errors involved in estimating $\mathrm{CO}$ production have been presented in the Methods section and discussed in a previous publication (1). Measurement of total $\mathrm{CO}$ produced should be accurate to better than $\pm 10 \%$.

It is assumed that the "extra" $\mathrm{CO}$ found was formed during hemoglobin catabolism via normal pathways. Although it seems unlikely, it is possible that injection of erythrocytes treated with NEM may stimulate $\mathrm{CO}$ production by some process other than hemoglobin degradation. The control experiments in dogs demonstrated that NEM itself is inert in this regard. The assumption that $\mathrm{CO}$ was produced as a result of hemoglobin degradation is supported by the demonstration that the serum bilirubin levels rose an average of $1.2 \mathrm{mg}$ per $100 \mathrm{ml}$ and appeared to parallel the $\mathrm{CO}$ production. The two studies employing cells labeled with $\mathrm{Cr}^{51}$ demonstrated that the administered hemoglobin was rapidly and nearly completely removed from the circulation and did not reappear for the duration of the experiment. Although we have assumed that the hemoglobin contained in the sequestered cells was catabolized, it was not possible to measure directly the amount of hemoglobin degraded in these experiments by an independent method.

In these studies it was important that the administered erythrocytes be sequestered promptly, so that complete hemoglobin degradation might be expected to occur during the time the subjects could be maintained in the rebreathing apparatus.
NEM was chosen as a convenient agent to alter the erythrocytes, so that they would be rapidly sequestered in vivo but not hemolyzed before injection (15).

In the experiments on subjects $R E, T P$, and $\mathrm{PK}$ the control $\mathrm{CO}$ production was measured before injection of the treated cells, and the values found were similar to those previously reported for normal male subjects (1). In each of these subjects the rate of $\mathrm{CO}$ production in the final hour of the study was still greater than the control value, and it was therefore necessary to alter the experimental design to determine precisely the time relationship of production of $\mathrm{CO}$ after injection and sequestration of the treated cells. For this purpose studies were performed on two subjects, $B D$ and $C B$, in which the treated cells were injected at the beginning of the experiment and estimation of $\mathrm{CO}$ production was continued until a constant rate was attained. In the experiment on $\mathrm{BD}$, treated cells containing $3.37 \mathrm{~g}$ of hemoglobin were injected (Figure 2). A total of $7.3 \mathrm{ml}$ of $\mathrm{CO}$ was produced in the first 3 hours, after which the production appeared to remain constant at a rate of $0.23 \mathrm{ml}$ per hour. In the experiment on CB, $1.54 \mathrm{~g}$ of hemoglobin was injected. In the first 2 hours $2.69 \mathrm{ml}$ of $\mathrm{CO}$ was produced, whereas $0.04 \mathrm{ml}$ was produced in the second and third 2-hour periods. It appears from these experiments that nearly all the "extra" $\mathrm{CO}$ is produced within 3 hours after injection of treated cells containing up to $3.3 \mathrm{~g}$ of hemoglobin, and we are justified in assuming that all, or nearly all, of the "extra" CO was measured in the first two experiments, subjects RE and TP. Subject $\mathrm{PK}$ received $5.28 \mathrm{~g}$ of hemoglobin and still produced a slightly elevated quantity of $\mathrm{CO}$ in the fourth hour after receiving the treated cells. By comparison with the other studies, apparently here too essentially all the "extra" CO was measured. Possibly CO production is delayed slightly after injection of larger quantities of hemoglobin. The average half-time of $\mathrm{CO}$ production following cell injection was 87 ( $\mathrm{SE}$ of mean \pm 3 ) minutes. This value is certainly a function of several variables, and determination of rate constants or definition of limiting reactions is impossible at present.

With these data we have calculated the ratio of "extra" $\mathrm{CO}$ produced to the quantity of heme 
administered in the treated cells. In these calculations we have assumed that the base-line rate of production of $\mathrm{CO}$ remains constant throughout the experiment. The "extra" CO produced after injection of the treated erythrocytes is then the difference between the total and base-line $\mathrm{CO}$ production. The results are presented in Table I. "Extra" CO was calculated in subjects RE, TP, and PK with the base-line CO production actually measured at the beginning of the experiment. For subjects $\mathrm{BD}$ and $\mathrm{CB}$ we used the average normal rate of $\mathrm{CO}$ production, $0.42 \mathrm{ml}$ per hour (1). This was necessary because in subject $\mathrm{CB}$ the rebreathing was unavoidably interrupted briefly twice during the last hour of the base-line measurement, and thus the values obtained are of uncertain significance. In the experiment on $\mathrm{BD}$ the base-line rate of $\mathrm{CO}$ production was determined during the latter part of the experiment and was significantly lower than the normal rate previously reported (1). We suggest that the large amount of $\mathrm{CO}$ produced and added to the blood stores during the first 2 to 3 hours of the experiment had not reached complete equilibrium with the extravascular stores; therefore, there was a small loss of $\mathrm{CO}$ from the blood to the extravascular stores during measurement of the base-line rate, leading to underestimation of this value. In this experiment $5.9 \mathrm{ml}$ of $\mathrm{CO}$ was produced during the first 2 hours of the experiment, and if only $5 \%$ of this quantity moved from the blood to the extravascular space in the period during which the base line was measured, this would have caused an underestimation of the rate of $\mathrm{CO}$ production of $0.09 \mathrm{ml}$ per hour, or about $20 \%$ of the normal rate.

In Figure 3 the "extra" $\mathrm{CO}$ produced in micromoles is plotted against the micromoles of heme injected. There is a significant correlation between these variables $(r=0.93)$, and the average molar ratio of "extra" $\mathrm{CO}$ to heme is 0.97 ( $\mathrm{SE}$ of mean \pm 0.06 ). It appears from the data presented that $\mathrm{CO}$ is produced in man as a result of hemoglobin degradation, and the quantity produced is approximately 1 mole of $\mathrm{CO}$ per mole of heme catabolized. The precise source of $\mathrm{CO}$ is as yet undefined; however, these findings are consistent with its origin from the $\alpha$ methene carbon atom of heme. The yield of $\mathrm{CO}$ from hemoglobin is higher than others have previously found for

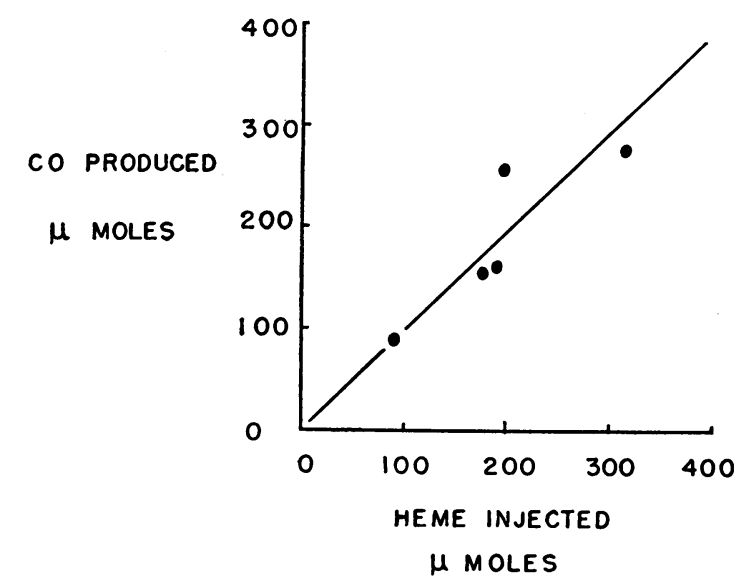

Fig. 3. Comparison of the amount OF INJECted HEME AND THE "EXTRA" CARBON MONOXIDE PRODUCED IN FIVE EXPERIMENTS. Both of these variables are expressed in micromoles.

bile pigment production from hemoglobin, where yields of 50 to $80 \%$ have been reported (17-20). An explanation of this apparent discrepancy between the efficiency of $\mathrm{CO}$ production from heme and bile pigment production from heme may lie in the fact that $\mathrm{CO}$ is probably produced in the initial steps of hemoglobin catabolism $(21,22)$ and is metabolically inert (23), whereas the remaining tetrapyrrole moiety is subject to a variety of reactions in the process of production of the bile pigments.

On the basis of the present study it seems very probable that $\mathrm{CO}$ produced as an end product of hemoglobin catabolism forms a large percentage of the normal $\mathrm{CO}$ production. In the study previously reported (1) it was found that the average normal rate of $\mathrm{CO}$ production is $0.42 \pm 0.02 \mathrm{ml}$ per hour. The average total body hemoglobin in this group of subjects was $724 \mathrm{~g}$. The average hourly rate of hemoglobin catabolism, assuming a mean erythrocyte survival time of 120 days, was $0.25 \mathrm{~g}$ per hour. This would result in a rate of carbon monoxide production, assuming a $0.97 \mathrm{M}$ ratio, of $0.32 \mathrm{ml}$ per hour from this source. Therefore, approximately $0.10 \mathrm{ml}$ per hour (the normal rate of $0.42 \mathrm{ml}$ per hour minus $0.32 \mathrm{ml}$ per hour) or $23 \%$ of the total average rate of $\mathrm{CO}$ production must arise from sources other than circulating hemoglobin. In this regard London, West, Shemin, and Rittenberg (24) found that about 10 to $15 \%$ of normal urobilin production arose from sources other than circulating hemo- 
globin. Possibly this portion of bile pigment production and approximately $0.10 \mathrm{ml}$ per hour of $\mathrm{CO}$ may originate from the same or similar processes.

\section{Summary}

We have investigated the effect of an increased rate of hemoglobin destruction upon the rate of endogenous $\mathrm{CO}$ production in one female and four male subjects. The hemoglobin destruction rate was increased by reinjecting the subject's own erythrocytes which had been treated with $N$-ethylmaleimide. In all subjects the rate of $\mathrm{CO}$ production increased after the injection of the cells. The amount of this increase corresponded to the formation of an average of $0.97 \pm 0.06$ mole $\mathrm{CO}$ for each mole of heme destroyed. This study provides evidence that $\mathrm{CO}$ is an in vivo end product of heme catabolism.

\section{Acknowledgments}

The authors gratefully acknowledge the expert technical assistance of Robert Ersek and Dolores Thyrum and the cooperation and help of Dr. William S. Blakemore.

\section{References}

1. Coburn, R. F., W. S. Blakemore, and R. E. Forster. Endogenous carbon monoxide production in man. J. clin. Invest. 1963, 42, 1172.

2. Sjöstrand, T. Endogenous formation of carbon monoxide in man under normal and pathological conditions. Scand. J. clin. Lab. Invest. 1949, 1, 201.

3. Sjöstrand, T. Endogenous formation of carbon monoxide. Acta physiol. scand. 1951, 22, 137.

4. Gydell, K. Transient effect of nicotinic acid on bilirubin metabolism and formation of carbon monoxide. Acta med. scand. 1960, 167, 431.

5. Engstedt, L. Endogenous formation of carbon monoxide in hemolytic disease with special reference to quantitative comparisons to other hemolytic indices. Acta med. scand. 1957, 159, suppl. 332.

6. Oski, F., and A. Altman. Carboxyhemoglobin levels in hemolytic disease of the newborn. J. Pediat. 1962, 61, 709.

7. Sjöstrand, T. The in vitro formation of carbon monoxide in blood. Acta physiol. scand. 1951, 24, 314.

8. Sjöstrand, T. The formation of carbon monoxide by in vitro decomposition of hemoglobin into bile pigment. Acta physiol. scand. 1952, 26, 328.
9. Ludwig, G. D., W. S. Blakemore, and D. L. Drabkin. Production of carbon monoxide by hemin oxidation (abstract). J. clin. Invest. 1957, 36, 912.

10. Petryka, Z., D. C. Nicholson, and C. H. Gray. Isomeric bile pigments as products of the in vitro fission of haemin. Nature (Lond.) 1962, 194, 1047.

11. Gray, C. H., D. C. Nicholson, and R. A. Nicolaus. The IX- $\alpha$ structure of the common bile pigments. Nature (Lond.) 1958, 181, 183.

12. Drabkin, D. L., and J. H. Austin. Spectrophotometric studies. V. A technique for the analysis of undiluted blood and concentrated hemoglobin solutions. J. biol. Chem. 1935, 112, 105.

13. McCall, K. B. Spectrophotometric determination of total hemoglobin in plasma. Analyt. Chem. 1956 28, 189.

14. Malloy, H. T., and K. A. Evelyn. The determination of bilirubin with the photoelectric colorimeter. J. biol. Chem. 1937, 119, 481.

15. Jacob, H. S., and J. H. Jandl. Effect of sulfhydryl inhibition on red blood cells. II. Studies in vivo. J. clin. Invest. 1962, 41, 1514.

16. Gray, S. J., and K. Sterling. The tagging of red cells and plasma proteins with radioactive chromium. J. clin. Invest. 1950, 29, 1604.

17. Sribbishaj, K., W. B. Hawkins, and G. H. Whipple. I. Bile pigment and hemoglobin interrelations in normal dogs. Amer. J. Physiol. 1931, 96, 449.

18. Cruz, W. O., W. B. Hawkins, and G. H. Whipple. Acetylphenylhydrazine anemia. II. Bile pigment elimination and new hemoglobin reconstruction in the bile fistula dog. Amer. J. med. Sci. 1942, 203, 848.

19. Ostrow, J. D., J. H. Jandl, and R. Schmid. The formation of bilirubin from hemoglobin in vivo. J. clin. Invest. 1962, 41, 1628.

20. Shen, S. C. Urobilinogen excretion after hemoglobin infusions in patients with normal hematologic and hepatic findings. Proc. Soc. exp. Biol. (N. Y.) 1960, 105, 264.

21. Lemberg, R., and J. W. Legge. Hematin Compounds and Bile Pigments. New York, Interscience, 1949.

22. Lemberg, $R$. The chemical mechanism of bile pigment formation. Rev. Pure appl. Chem. 1956, 6, 1.

23. Tobias, C. A., J. H. Lawrence, F. J. W. Roughton, W. S. Root, and M. I. Gregersen. The elimination of carbon monoxide from the human body with reference to the possible conversion of $\mathrm{CO}$ to $\mathrm{CO}_{2}$. Amer. J. Physiol. 1946, 145, 253.

24. London, I. M., R. West, D. Shemin, and D. Rittenberg. On the origin of bile pigment in normal man. J. biol. Chem. 1950, 184, 351. 